\title{
Sosialisasi Dan Penyuluhan Budidaya Pisang Dengan Bibit Hasil Kultur Jaringan Di Desa Lempong, Kecamatan Jenawi, Kabupaten Karanganyar
}

\author{
Samanhudi $^{1}$, Hery Widijanto ${ }^{2) *}$, Ahmad Yunus ${ }^{1}$ \\ ${ }^{1}$ Program Sudi Agrotekonologi Fakultas Pertanian UNS dan Pusat Penelitian dan \\ Pengembangan Bioteknologi dan Biodiversitas LPPM UNS \\ ${ }^{2}$ Program Studi Ilmu Tanah Fakultas Pertanian UNS \\ *Correspoding Author : herywidijanto@staff.uns.ac.id
}

\begin{abstract}
ABSTRAK
Komoditas lokal yang diunggulkan dari Kecamatan Jenawi adalah pisang dan telah banyak dipasarkan di daerah Surakarta. Produksi pisang harus diimbangi dengan pemenuhan bibit yang memadai. Penggunaan bibit pisang dari kultur jaringan dapat diperoleh hasil yang memenuhi standar kuantitas maupun kualitas. Bibit pisang hasil kultur jaringan bersifat seragam, lebih resisten hama maupun penyakit, dan dapat disediakan bibit dalam jumlah cukup banyak setiap saat. Kegiatan pengabdian masyarakat ini melibatkan dua Mitra, yaitu Kelompok Tani (KT) Lawu Makmur dan KT Subur Makmur di wilayah Desa Lempong, Kecamatan Jenawi, Kabupaten Karanganyar. Kegiatan dilakukan pada bulan April sampai dengan bulan Oktober 2019. Beberapa jenis pisang yang disiapkan untuk pengembangan antara lain kultivar Rajabulu, Barangan, Mas Kirana, dan Kepok. Metode kegiatan dilakukan dengan melibatkan petani secara langsung, baik dalam pertemuan-pertemuan teknis maupun dalam praktik langsung di lapangan. Kegiatan yang dilakukan meliputi; penyiapan bibit pisang, koordinasi dengan mitra, sosialisasi hasil kultur jaringan, dan penyuluhan budidaya pisang dengan bibit hasil kultur jaringan. Hasil kegiatan menunjukkan bahwa penyiapan bibit pisang hasil kultur jaringan dapat dilakukan dengan baik. Sosialisasi dan penyuluhan budidaya pisang dengan bibit hasil kutur jaringan dapat terlaksana dan diikuti oleh petani dari Kelompok tani Mitra. Hasil akhir kegiatan petani dapat memperoleh pemahaman tentang bibit hasil kultur jaringan dan menggunakan bibit tersebut dalam budidaya.
\end{abstract}

Kata kunci: bibit pisang, kultur jaringan, Jenawi.

\begin{abstract}
The local commodity that is seeded from Jenawi sub-district is bananas and has been widely marketed in Surakarta area. Banana production must be balanced with adequate seedling fulfillment. The use of banana seedlings from tissue cultures can be obtained results that meet both quantity and quality standards. Banana seedlings result from uniform tissue culture, more pest and disease resistant, and can be provided in sufficient quantities at any time. This community service activity involved two Partners, namely Farmers Group (FG) Lawu Makmur and FG Subur Makmur in Lempong Village, Jenawi Sub-District, Karanganyar Regency. Activities are carried out from April to October 2019. Some types of bananas prepared for development include Rajabulu cultivars, Barangan, Mas Kirana, and Kepok. The activity method is carried out by engaging farmers directly, both in technical meetings and indirect practice in the field. Activities include preparing banana seedlings, coordinating with partners, socialization of tissue culture results, and extension of banana cultivation with tissue culture seedling. The results of the activity show that the preparation of banana seedlings resulting from tissue culture can be done well. Socialization and extension of banana cultivation with the seeds of tissue crops can be carried out and followed by farmers from partner Farmer Group. The end result of farmer activities can understand about the seedlings of tissue culture and use the seeds in their cultivation.
\end{abstract}

Keywords: banana seed, tissue culture, Jenawi 


\section{PENDAHULUAN}

Pisang merupakan tanaman hortikultura dalam kelompok buah yang memiliki nilai ekonomi yang tinggi. Pisang dapat beradaptasi dengan baik pada daerah tropis lembab hingga sub tropis sampai ketinggian $2000 \mathrm{~m}$ di atas permukaan laut, baik di Afrika, Amerika dan Asia termasuk Indonesia (Dikayani et al., 2017; Kishor. et al., 2017). Di Indonesia, pisang adalah buah yang dapat dikonsumsi oleh masyarakat dalam bentuk produk segar maupun olahan. Kebutuhan pisang yang meningkat harus seimbang dengan metode budidaya yang efektif dan pruduksi yang tinggi (Mardhikasari et al., 2019). Pisang di Kabupaten Karanganyar umumnya berasal dari beberapa varietas unggul dan memiliki tingkat kompetitif tinggi dikarenakan pertumbuhannya yang cukup cepat, rasa yang manis, dan kandungan Vitamin yang cukup tinggi (vitamin A dan C), sehingga pisang ini sangat populer di masyarakat (Herawati et al., 2018). Beberapa permasalahan muncul ketika pisang dibudidayakan oleh masyarakat. Masalah timbul karena petani pisang belum memahami cara yang tepat dalam melakukan perbanyakan bibit. Bibit pisang sulit untuk didapatkan dalam jumlah yang banyak, memerlukan biaya yang tinggi dan waktu lama dalam pembibitannya, bibit yang tumbuh tidak seragam, anakan mudah terserang penyakit, serta proses pengepakan dan pengiriman bibit yang kurang efisien. Untuk mengatasi masalah penyediaan bibit tersebut, telah dikembangkan perbanyakan tanaman pisang secara kultur jaringan. Kultur jaringan sebagai teknik bioteknologi modern, dianggap sebagai satu metode pemuliaan penting untuk banyak tanaman, sayuran dan buah-buahan, dan menjadi metode pengganti untuk perbanyakan vegetatif secara konvensional (El-Sherif, 2019). Kultur jaringan tanaman merupakan teknik kultur dari sel tanaman, jaringan dan organ pada media buatan di lingkungan aseptik dan kondisi cahaya, suhu, mapun kelembapan selalu terkontrol (Dagla, 2012; Espinosa-Leal et al., 2018). Kultur jaringan tanaman saat ini menjadi teknologi mapan yang telah memberikan kontribusi nyata dalam perbanyakan tanaman dan peningkatan pertanian secara umum (AkinIdowu et al., 2009). Tanaman hasil kultur jaringan dicirikan dengan pertumbuhan yang bebas penyakit, sistem perakaran lebih berserat, sistem akar lebih sehat, percabangan akan lebih rimbun, dan tingkat kemampuan hidup akan lebih tinggi (Asmita et al., 2017). di Indonesia beberapa kultivar pisang telah banyak dihasilkan oleh instansi pemerintahan misalnya Kebun Plasma Koleksi Plasma Nutfah Pisang Cibinong, Pusat Penelitian Hortikultura sub-stasiun Tlekung di Jawa Timur, dan Kebun Plasma Nutfah Pisang di Kotamadya Yogyakarta (Jumari \& Pudjoarinto, 2000).

Tujuan kegiatan ini adalah untuk memberikan sosialisasi tentang teknik kultur jaringan dan penyuluhan tentang budidaya pisang hasil kultur jaringan kepada petani mitra. Hasil akhir dari kegiatan diharapkan petani mitra dapat memahami teknik kultur jaringan untuk perbanyakan bibit dan dapat meningkatkan produksi pisang yang memenuhi standar kualitas maupun kuantitas.

\section{METODE}

Kegiatan pengabdian ini dilakukan di Desa Lempong, Kecamatan Jenawi, Kabupaten Karanganyar dengan melibatkan 2 (dua) kelompok tani (KT), yaitu KT Lawu Makmur dan KT Subur Makmur. Kedua kelompok tani tersebut saat ini sudah menanam pisang, namun teknik budidaya masih dilakukan secara konvensional sehingga produksi belum bisa maksimal. Dengan dijadikan subyek dan sasaran dalam kegiatan ini diharapkan ke depan petani semakin maju dan intensif didalam mengelola kebun pisangnya dan menularkan ilmunya kepada petani yang lain.

Metode kegiatan dilakukan dengan melibatkan partisipasi petani secara langsung, baik dalam sosialisasi maupun penyuluhan. Metode partisipasi dicirikan dengan anggota masyarakat secara langsung ikut terlibat dalam kegiatan dengan memberikan bantuan tenaga (Rubiantoro \& Haryanto, 2013). Petani yang telah mengikuti kegiatan ini diharapkan dapat menerapkan teknik budidaya pisang menggunakan bibit kultur jaringan. Bibit yang digunakan merupakan hasil kegiatan penelitian tim di Fakultas Pertanian. Monitoring akan dilakukan setelah bibit piang hasil kultur jaringan ditanam oleh petani.

\section{HASIL DAN PEMBAHASAN}

Kegiatan yang dilakukan meliputi: (1) penyiapan bibit pisang; (2) sosialisasi tentang kultur jaringan; (3) penyuluhan budidaya pisang dengan bibit hasil kultur jaringan dan; (4) penyerahan bibit pisang hasil kultur jaringan. 


\section{Penyiapan bibit pisang}

Kegiatan penyiapan bibit pisang hasil dari kultur jaringan dilakukan dengan beberapa tahap. Perbanyakan bibit pisang secara kultur jaringan tanaman pisang dilakukan di Laboratorium Fisiologi Tumbuhan dan Bioteknologi Fakultas Pertanian UNS. Proses aklimatisasi dilakukan untuk menguji apakah bibit yang dihasilkan di laboratorium dapat beradaptasi dan tumbuh baik di lapangan. Penyiapan bibit selanjutnya dilakukan di Laboratorium Jumantono Karanganyar, sampai dihasilkan bibit pisang yang siap diberikan ke petani. Kegiatan penyiapan bibit pisang ini sesuai dengan langkah-langkah perbanyakan dengan kultur jaringan. Bibit pisang ditanam dalam polybag dengan media tanah, pupuk organik dan mikoriza. Hal ini sesuai dengan penelitian bahwa aklimatisasi dan perbanyakan plantlet pisang sangat bergantung pada media pertumbuhan, dan tanah merupakan substrat terbaik untuk kolonisasi akar dan aktivitas mycorrhiza (Ortas et al., 2017). Penggunaan jamur Mikoriza Arbuskular (Glomus tipe-1, Acaulospora tipe-4, Glomus fasciculatum) dapat meningkatkan pertumbuhan biji tanaman pisang Barangan (tinggi tanaman dan jumlah daun) (Indrawati \& Suswati, 2019).

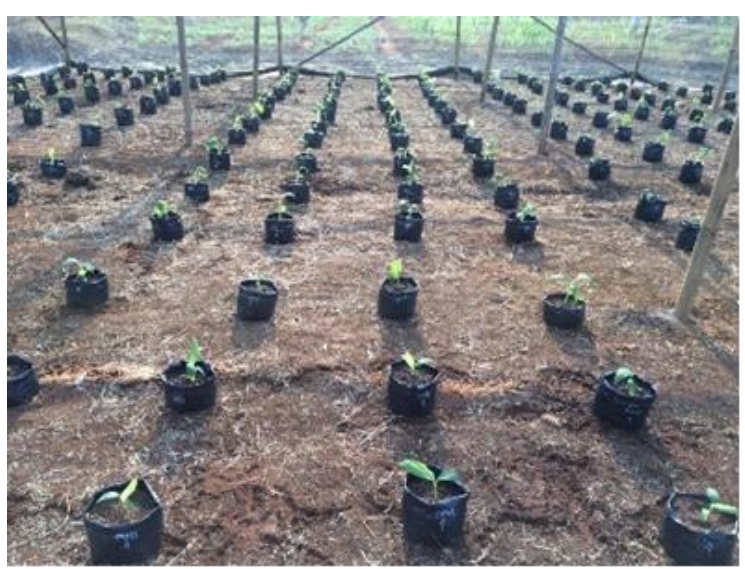

Gambar 1. Bibit pisang saat awal aklimatisasi

Gambar 1 memperlihatkan bibit pisang pada awal aklimatisasi. Bibit pisang ditempatkan di bawah paranet dengan intensitas $60 \%$. Pemeliharaan dilakukan selama pertumbuhan, dengan melakukan penyiraman dan pembersihan gulma. Gambar 2 menunjukkan bibit pisang yang siap untuk dibagikan ke petani. Bibit pisang berumur 45 hari setelah aklimatisasi awal. Tanaman pisang yang disiapkan untuk petani sejumlah 250 bibit.

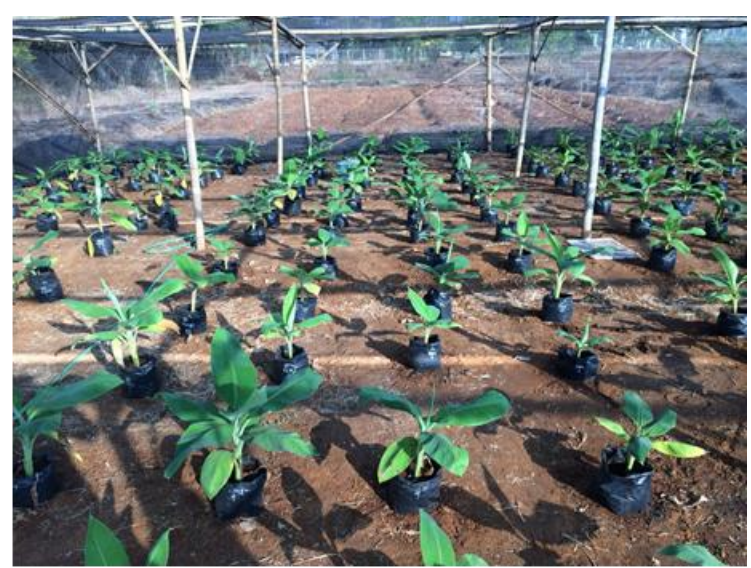

Gambar 2. Bibit pisang siap ditanam di lapangan

\section{Sosialiasi dan penyuluhan}

Sosialisasi dan penyuluhan dilakukan Senin, 14 Oktober 2019 bertempat di Kantor Kepala Desa Lempong, Kecamatan Jenawi, Kabupaten Karanganyar. Kegiatan ini diikuti 40 peserta yang merupakan perwakilan petani dari 2 Kelompok Tani Mitra, juga dihadiri perangkat desa dan penyuluh pertanian. Materi yang diberikan dalam sosialisasi dan penyuluhan antara lain : (1) informasi tentang bibit pisang hasil kultur jaringan dan (2) teknologi budidaya pisang.

Sosialisasi diberikan informasi tentang pengertian kultur jaringan, kelebihan perbanyakan bibit dengan kutur jaringan (Gambar 3). Kultur jaringan tanaman adalah teknik menumbuhkan sel tanaman, jaringan dan organisme pada media nutrisi buatan yang disiapkan dalam kondisi aseptic (Asmita et al., 2017). Kultur jaringan tanaman adalah metode untuk kultur sel, organ jaringan dan komponen lain dari tanaman mengikuti kultur in-vitro aseptik di bawah lingkungan yang terkontrol dengan baik. Dengan cara yang sederhana, jika bagian dari tubuh tanaman dibedah menjadi bagian kecil yang disebut explant dan bagian kecil tersebut dapat ditanam menjadi tanaman lengkap (Twaij et al., 2020). Sistem kultur jaringan menyediakan semua hara, air, dan sumber energi untuk pertumbuhan tanaman atau eksplan tanaman melalui media yang bersifat basal (Phillips \& Garda, 2019).

Penyuluhan tentang budidaya pisang dengan bibit hasil kultur jaringan dilakukan dengan penyampaian materi dan diskusi (Gambar 4). Dalam diskusi, petani bertanya tentang bagaimana perbedaan bibit hasil kultur jaringan dengan bibit yang konvensional. 


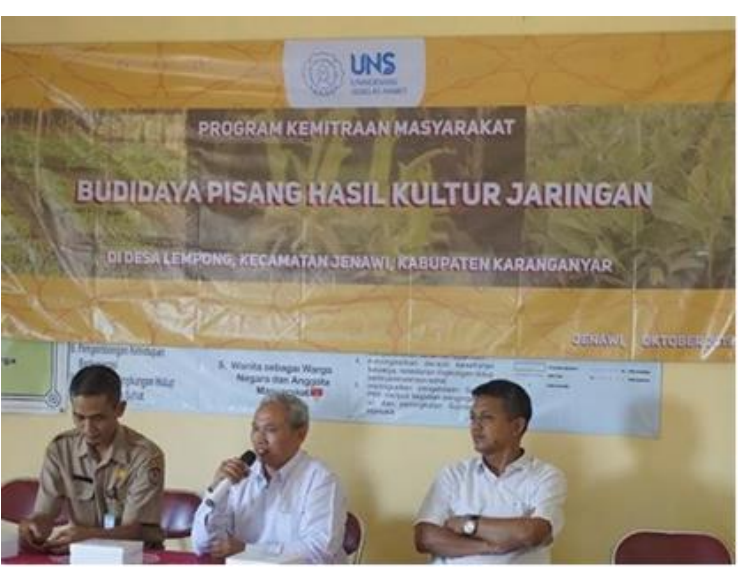

Gambar 3. Sosialisasi tentaanh bibit kultur jaringan oleh ketua tim pengabdian

Pertanyaan lain yang muncul antara lain bagaimana penggunaan pupuk dan langkahlangkah pengendalian OPT (Organisme Pengganggu Tumbuhan) yang perlu dilakukan. Pemupukan perlu dilakukan untuk meningkatkan pertumbuhan dan hasil pisang. Penggunaan pupuk organik dapat memperbaiki sifat fisika, kimia, biologis, dan kesehatan tanah serta meningkatkan hasil pisang (Zhang et al., 2019). Penambahan pupuk kalium mampu meningkatkan diameter batang, mempercepat keluarnya jantung, mempercepat panen dan meningkatkan hasil pisang (Muas et al., 2019).

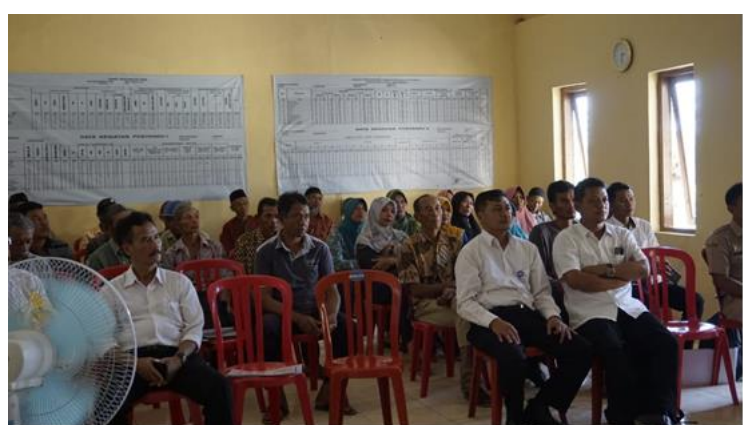

Gambar 4. Diskusi dalam penyuluhan budidaya pisang dengan bibit hasil kultur jaringan

\section{Penyerahan bibit Pisang}

Di akhir kegiatan sosialisasi dan penyuluhan, dilakukan penyerahan bibit pisang hasil kultur jaringan kepada dua kelompok tani pisang, yaitu KT Lawu Makmur dan KT Subur Makmur (Gambar 5). Bibit pisang hasil kultur jaringan berjumlah 250 tanaman yang terdiri atas kultivar Rajabulu, Barangan, Mas Kirana dan Kepok. Kegiatan penanaman dan pemeliharaan bibit pisang hasil kultur jaringan yang diberikan pada kegiatan ini dikoordinir oleh ketua kelompok tani mitra, dengan monitoring dari penyuluh dan perangkat desa setempat.

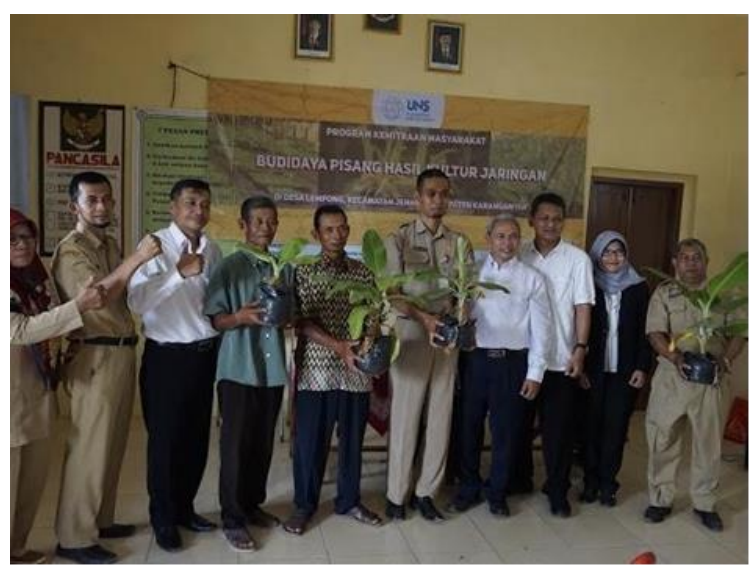

Gambar 5. Penyerahan bibit pisang hasil kultur jaringan

\section{KESIMPULAN}

Secara keseluruhan kegiatan dapat dilaksanakan dengan baik. Penyiapan bibit pisang hasil kultur jaringan dilakukan di laboratorium lahan kering Jumantono, Karanganyar. Sosialisasi yang dilakukan dapat menambah pengetahuan dan pemahaman petani tentang bibit kultur jaringan. Penyuluhan budidaya pisang dengan bibit hasil kutur jaringan diikuti oleh petani dari Kelompok tani Mitra terlaksana dengan baik dan lancar. Bibit pisang kultur jaringan diberikan kepada petani peserta untuk ditanam di lahan masing-masing. Hasil akhir kegiatan petani memperoleh pemahaman tentang bibit hasil kultur jaringan dan menggunakan bibit hasil kultur jaringan dalam budidayanya.

\section{UCAPAN TERIMA KASIH}

Ucapan terimakasih disampaikan kepada Universitas Sebelas Maret (UNS) yang telah mendanai kegiatan ini melalui Anggaran PNBP tahun 2019.

\section{DAFTAR PUSTAKA}

Akin-Idowu, P. E., Ibitoye, D. O., \& Ademoyegun, O. T. (2009). Tissue culture as a plant production technique for horticultural crops. African Journal of Biotechnology, 8(16), 3782-3788. https://doi.org/10.5897/AJB2009.0009374

Asmita, V. G., Singh, S. K., \& Gilhotra, R. 
(2017). Plant tissue culture - a review. SGVU Journal of Pharmaceutical Research \& Education, 2(1), 217-220. http://www.gyanvihar.org/researchjourna ls/

Dagla, H. R. (2012). Plant tissue culture: Historical developments and applied aspects. Resonance, 17(8), 759-767. https://doi.org/10.1007/s12045-0120086-8

Dikayani, Anas, Nuraini, A., \& Ali Qosim, W. (2017). Response of Shoot and Root in vitro Cultures of Banana Plant (Musa acuminata L.) cv Barangan to Salinity Stresses. Asian Journal of Agricultural Research, 11(4), 103-107. https://doi.org/10.3923/ajar.2017.103.107

El-Sherif, N. A. (2019). Impact of plant tissue culture on agricultural sustainability. Handbook of Environmental Chemistry, 77 , 93-107. https://doi.org/10.1007/698_2017_160

Espinosa-Leal, C. A., Puente-Garza, C. A., \& García-Lara, S. (2018). In vitro plant tissue culture: means for production of biological active compounds. Planta, 248(1). https://doi.org/10.1007/s00425018-2910-1

Herawati, A., Mujiyo, Widijanto, H., Isnaini, \& Romdhati, F. (2018). Land conservation on banana cultivation based on erosion risks level at Jenawi DistrictKaranganyar, Indonesia. IOP Conference Series: Earth and Environmental Science, 200(1),

$0-8$. https://doi.org/10.1088/17551315/200/1/012014

Indrawati, A., \& Suswati, S. (2019). The Effectiveness of Endomycorrhiza Species on the Growth of Barangan Banana Seedlings. Budapest International Research in Exact Sciences (BirEx) Journal, $1(4), \quad 70-76$ https://doi.org/10.33258/birex.v1i4.479

Jumari, \& Pudjoarinto, A. (2000). Kekerabatan Fenetik Kultivar Pisang Di Jawa. Jurnal ILib UGM. http://ilib.ugm.ac.id/jurnal/download.php?dataI $\mathrm{d}=330$

Kishor., H., Abhijith, Y. ., \& Manjunatha, N. (2017). Micropropagation of Native Cultivars of Banana- A Critical Review. International Journal of Pure \& Applied Bioscience, 5(5), 1559-1564. https://doi.org/10.18782/2320-7051.5209
Mardhikasari, S., Yunus, A., \& Samanhudi, S. (2019). Modification of Media for Banana In Vitro Propagation with Foliar Fertilizer and Coconut Water in cv. Rajabulu. Caraka Tani: Journal of Sustainable Agriculture, 35(1), 23. https://doi.org/10.20961/carakatani.v35i1 .27756

Muas, I., Jumjunidang, N., Hendri, N., Emilda, D., \& Fatria, D. (2019). Efek Aplikasi Fungi Mikoriza Arbuskula dan Pupuk KaliumTerhadap Pertumbuhan dan Produksi Pisang Ketan (Effects of Arbuscular Mycorrhizal Fungi and Potash Fertilizer Application on the Growth and Production of Banana cv. Ketan). Jurnal Hortikultura, 29(1), 61. https://doi.org/10.21082/jhort.v29n1.201 9.p61-68

Ortas, İ., Rafique, M., Akpinar, C., \& Kacar, Y. A. (2017). Growth media and mycorrhizal species effect on acclimatization and nutrient uptake of banana plantlets. Scientia Horticulturae, 217, 55-60. https://doi.org/10.1016/j.scienta.2017.01. 025

Phillips, G. C., \& Garda, M. (2019). Plant tissue culture media and practices: an overview. In Vitro Cellular and Developmental Biology - Plant, 55(3), 242-257. https://doi.org/10.1007/s11627-01909983-5

Rubiantoro, E. A., \& Haryanto, R. (2013). Bentuk Keterlibatan Masyarakat dalam Upaya Penghijauan pada Kawasan Hunian Padat di Kelurahan Serengan Kota Surakarta. Jurnal Pembangunan Wilayah \& Kota, 9(4), 416. https://doi.org/10.14710/pwk.v9i4.6679

Twaij, B. M., Jazar, Z. H., \& Hasan, M. N. (2020). Trends in the use of tissue culture, applications and future aspects. International Journal of Plant Biology, 11(1), 1-14. https://doi.org/10.4081/pb.2020.8385

Zhang, J., Bei, S., Li, B., Zhang, J., Christie, P., \& Li, X. (2019). Organic fertilizer, but not heavy liming, enhances banana biomass, increases soil organic carbon and modifies soil microbiota. Applied Soil Ecology, 136(May 2018), 67-79. https://doi.org/10.1016/j.apsoil.2018.12.0 17 